\title{
Dabīgu un apstrādātu mālu antimikrobiālā aktivitāte
}

\author{
Vizma Nikolajeva ${ }^{1}$, Tatjana Griba ${ }^{2}$, Zaiga Petriņa ${ }^{3}$, Jūlija Karasa ${ }^{4}$, \\ ${ }^{1-4}$ Latvijas Universitāte
}

\begin{abstract}
Kopsavilkums. Pētīta dabisku mālu un termiski un ķīmiski apstrādātu māla materiālu antimikrobiālā aktivitāte. Pētītajiem Latvijas dabiskajiem māliem nav konstatēta antimikrobiāla iedarbība. Prometeja atradnes māla keramikas granulas ūdens vidē inhibēja baktēriju augšanu. Antimikrobiālā aktivitāte skaidrota ar bāzisko metālu oksīdu saturu. Katjonu virsmas aktīvās vielas saturoši māli uzrādīja antibakteriālu un antifungālu iedarbību. Paveras iespējas izstrādāt jaunas antimikrobiālu māla materiālu iegūšanas tehnoloğijas un produktus.
\end{abstract}

Atslēgas vārdi: māls, keramika, antibakteriālā aktivitāte, antifungālā aktivitāte.

\section{IEVADS}

Māli ir visizplatītākie nogulumieži, kas veido lielāko dal̦u Zemes garozas augšējo horizontu [1]. Pēc apstrādes tos plaši lieto dažādiem nolūkiem: ražo būvmateriālus, traukus, kosmētiskos līdzekļus un izmanto biotehnoloǵijā.

Latvijā ieguvei piemērotā dziḷumā māli atrodas devona, triasa, juras un kvartāra nogulumos, bet plaša rūpnieciska nozīme ir tikai devona un kvartāra māliem. Abi mālu veidi sastāv galvenokārt no illīta (80-100 \%) un kaolinīta (līdz $20 \%$ ) ar hlorīta (5-10\%) piemaisījumu. Devona māliem ir raksturīgs samērā augsts brīvo dzelzs oksīdu un hidroksīdu saturs, kas piešksir māliem sarkanu krāsu. Savukārt kvartāra māli ir karbonātiski. Tie satur kalcīta un dolomīta piejaukumus, un to sastāvam ir raksturīgs $\mathrm{CaO}$ (vidēji 8-9 \%) un $\mathrm{MgO}(3,5-4 \%)$ [1].

Pētījumi rāda, ka porainus māla nesējus, uz kuriem imobilizēti mikroorganismi, var izmantot notekūdenu attīrǐšanā [2], vides bioremediācijā [3-5] un citos biotehnoloǵiskos procesos. Māli parasti rada mikroorganismiem draudzīgu vidi [6], bet tie var būt arī ar antimikrobiālu aktivitāti, kas var tikt izmantota, piemēram, medicīnā un būvmateriālu ražošanā.

Pasaulē ir aprakstīti tikai daži dabiski antibakteriāli māli [7]. Tie, ko sauc par dziedinošiem māliem - parasti tie ir nātrija vai kalcija bentonīti -, ne vienmēr ir ar antibakteriālu iedarbību, jo dziedināšanas pamatā var būt arī fizikālas īpašības, piemēram, absorbcijas spēja, siltuma kapacitāte, apmaiņas īpašības u.c. [8]. Mālu izmantošanai medicīnā ir senas tradīcijas, un tās var iedalīt divās dal̦ās. Viena daļa ir saistīta ar toksīnu un citu savienojumu fizikālu sorbciju uz māla daļiņām ar tai sekojošu izvadīšanu vai atdalīšanu no organisma, bet otra daḷa - ar mālu antimikrobiālajām īpašībām [8].
Mālu antimikrobiālā darbība iegūst arvien lielāku praktisku nozīmi, jo nepārtraukti palielinās patogēno baktēriju rezistence pret antibiotikām. Izmantojot mālam raksturīgo katjonu apmaiņas kapacitāti, ir izveidoti māla minerāli, kas satur antibakteriālus sudraba vai vara jonus [9]. Antibakteriālas īpašības ir aprakstītas vairākiem metālu oksīdiem, piemēram, cinka oksīdam, magnija oksīdam un kalcija oksīdam [10], kas lielākā vai mazākā koncentrācijā atrodas mālos. Plaša spektra bakteriostatiska un baktericīda iedarbība aprakstīta arī vairākiem dabiskiem, k̦īmiski nemodificētiem māliem un māla minerāliem [8, 11-13].

Š̀ darba mērķis bija noskaidrot, vai dabīgajiem Latvijas māliem, kā arī dažādi apstrādātiem māliem un to materiāliem piemīt antimikrobiālā aktivitāte.

\section{MATERIĀLI UN METODES}

\section{Izmantotie mālu materiāli}

Eksperimentos izmantotie Latvijas devona perioda (Lažas, Planču atradnes) un kvartāra perioda (Prometeja atradne) māli un šūnainās keramikas granulas tika sagatavotas un raksturotas RTU Silikātu materiālu institūtā (R. Švinka, V. Švinka; 1. tabula). Daḷa no Prometeja māla granulām tika apdedzinātas pie divām atšķirīgām temperatūrām un sasmalcinātas $l \bar{l} d z$ divām atšksirīgām frakcijām. Ieguvām četrus paraugus, apdedzinātus dažādā temperatūrā:

1) $1000{ }^{\circ} \mathrm{C}$, dalinu izmērs $<200 \mu \mathrm{m}$;

2) $1000^{\circ} \mathrm{C}$, dalịnu izmērs $>200 \mu \mathrm{m}$;

3) $800{ }^{\circ} \mathrm{C}$, dalịinu izmērs $<200 \mu \mathrm{m}$;

4) $800^{\circ} \mathrm{C}$, dalinu izmērs $>200 \mu \mathrm{m}$.

Saltišksu karjera (Lietuva) triasa perioda smektīta māli tika apstrādāti LU Ķ̄̄mijas fakultātē. Antibakteriālā un antifungālā efekta pārbaudei tika izmantoti dabiskie Saltišksu atradnes māli, bagātinātie māli, kā arī šo bagātināto mālu organokompleksi ar katjonu virsmas aktīvajām vielām: A oktadeciltrimetilamonija hlorīdu (ODTMA; $\mathrm{C}_{21} \mathrm{H}_{46} \mathrm{NCl}$, Fluka Chemica) 1,5 mmol uz 1 g mālu; B - heksadeciltrimetilamonija bromīdu (HDTMA; $\mathrm{C}_{19} \mathrm{H}_{42} \mathrm{NBr}$, Chemapol, Lachema) 1,0 mmol uz 1 g mālu (1. attēls). Bagātināto mālu iegūšanai māli tika speciāli attīīiti [14], un pēc attīrīšanas tie saturēja mazāk kvarca (ne vairāk par 3 \%), un tajos nebija dolomīta un kalcīta (pēc rentgendifraktometrijas analīžu datiem). Iegūtie organokompleksi saturēja attiec̄̄gi $34 \%$ ODTMA vai $27 \%$ HDTMA. Saltišķu un Prometeja atradnes mālu ķīmiskais sastāvs (2. tabula) tika analizēts LU Ķ̄imijas fakultātē, izmantojot viḷnu dispersijas spektrometru Bruker S8 Tiger. 


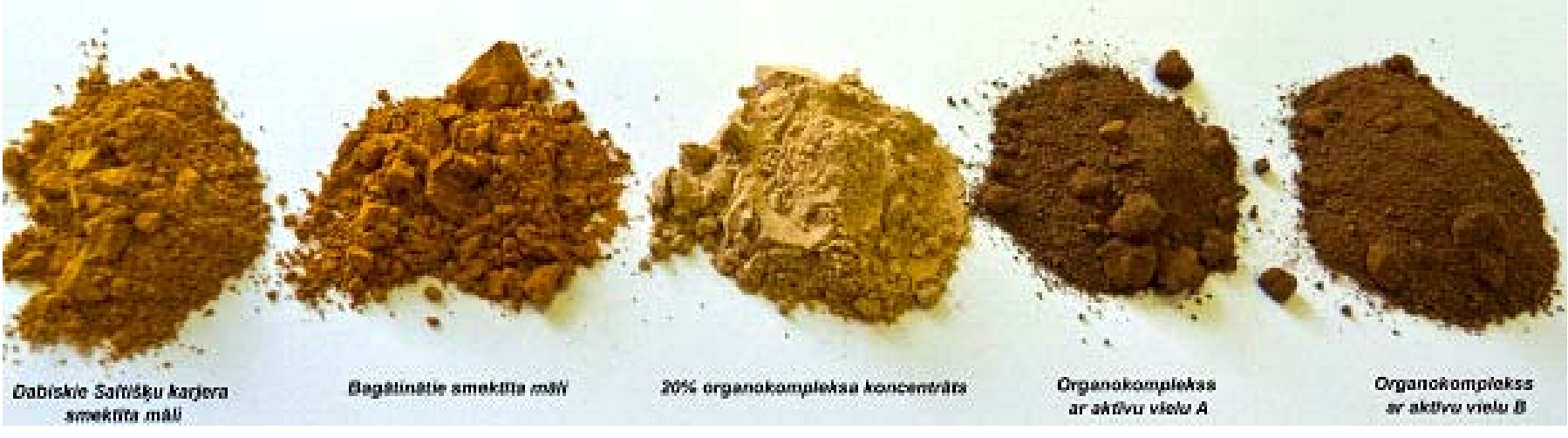

1.att. Dabiskie un apstrādātie Saltišķu atradnes māli.

1. TABULA

IZMANTOTO KERAMIKAS GRANULU RAKSTUROJUMS

\begin{tabular}{|c|c|c|}
\hline $\begin{array}{c}\text { Māli un māla granulu } \\
\text { apdedzināšanas temperatūra }\end{array}$ & Diametrs, cm & Blīvums, $\mathrm{g} / \mathrm{cm}^{3}$ \\
\hline Devona $1150^{\circ} \mathrm{C}$ & 1,3 & 1,30 \\
\hline Devona $1200^{\circ} \mathrm{C}$ & 1,4 & 1,04 \\
\hline Kvartāra $1100^{\circ} \mathrm{C}$ & 1,2 & 1,33 \\
\hline Kvartāra $1150^{\circ} \mathrm{C}$ & 1,2 & 0,55 \\
\hline
\end{tabular}

\section{Izmantotie mikroorganismi}

Darbā izmantots mikroskopiskās sēnes Cladosporium herbarum celms LMKK 258 un trīs baktēriju tīrkultūras: Pseudomonas putida LMKK 650, Staphylococcus aureus LMKK 334 un Escherichia coli LMKK 332.

\section{Antibakteriālās aktivitātes noteikšana}

Eksperimenti ar māliem noritēja $30 \mathrm{ml}$ tilpuma sterilās stikla pudelēs (Simax, Čehija), kur sterilizēti $\left(121^{\circ} \mathrm{C} 15 \mathrm{~min}\right.$.) $1 \mathrm{~g}$ vai $3 \mathrm{~g}$ māla paraugu kopā ar $10 \mathrm{ml}$ baktēriju $P$. putida, $S$. aureus vai $E$. coli ūdens suspensijas $\left(\mathrm{OD}_{540} 0,05-0,06\right.$; Ultrospec 3100 pro, Amersham Biosciences, Lielbritānija) tika inkubēti no vienas līdz četrām stundām $30{ }^{\circ} \mathrm{C}$ temperatūrā. Pēc tam tika gatavotas suspensiju atšķaidījumu sērijas un veikti baktēiiju uzsējumi Petri traukos uz mikrobiologiskās barotnes (Plate Count agar, Bio-Rad, Francija). Petri trauki tika inkubēti vienu (E. coli) vai divas (P. putida, S. aureus) dienas $28{ }^{\circ} \mathrm{C}$ temperatūrā. Pēc tam tika saskaitītas baktēriju kolonijas un aprēķināts kolonijas veidojošo vienību (kvv) skaits uz vienu gramu māla materiāla. Noteikšanas apakšējā robeža bija $10 \mathrm{kvv}$ uz vienu mililitru un $2 \mathrm{kvv}$ uz vienu gramu māla materiālu.

Eksperimenti ar keramikas granulām noritēja $100 \mathrm{ml}$ tilpuma stikla pudelēs, kur $15 \mathrm{~g}$ autoklāvā sterilizētu $\left(121{ }^{\circ} \mathrm{C}\right.$ 15 min.) granulu tika aplietas ar $50 \mathrm{ml}$ sterila destilēta ūdens un $P$. putida suspensiju ar blīvumu $\mathrm{OD}_{540} 0,05-0,06$. Baktērijas tika inkubētas termostatā (Binder KB 53, Vācija) $20^{\circ} \mathrm{C}$ vai $30{ }^{\circ} \mathrm{C}$ četras stundas, manuāli samaisot divas reizes stundā. Paraugi mikrobiolog̣iskām analīzēm tika ņemti pēc vienas un četrām stundām. Pēc četrām stundām šķidrums tika dekantēts, bet granulas tika divas reizes atmazgātas ar PBS škīidumu $\left(137 \mathrm{mM} \mathrm{NaCl}, 2,7 \mathrm{mM} \mathrm{KCl}, 10 \mathrm{mM} \mathrm{KH} \mathrm{PO}_{4}\right.$, pH 7,4) un saberztas sterilā piestināa nelielā PBS daudzumā, lai atdalītu pie granulām adsorbētās baktērijas. Pēc tam tika noteikts no granulām atdalīto baktēriju daudzums un izteikts kolonijas veidojošās vienībās uz gramu granulu. Eksperiments tika atkārtots trīs reizes.

2. TABULA

MĀLU KĪMISKAIS SASTĀVS, IZTEIKTS OKSĪDU FORMULVIENĪBU MASAS PROCENTOS

\begin{tabular}{|c|c|c|c|c|c|}
\hline \multirow[t]{2}{*}{ Formula } & \multirow{2}{*}{$\begin{array}{l}\text { Neapstrādāts Planču } \\
\text { atradnes māls (Muter et } \\
\text { al., 2012) }\end{array}$} & \multicolumn{2}{|c|}{ Prometeja atradnes māls } & \multicolumn{2}{|c|}{ Saltišķu atradnes māls } \\
\hline & & neapstrādāts & $\begin{array}{l}\text { sasmalcinātas keramikas } \\
\text { granulas }\end{array}$ & neapstrādāts & bagātināts \\
\hline $\mathrm{SiO}_{2}$ & 73,56 & 41,36 & 42,39 & 54,60 & 58,90 \\
\hline $\mathrm{Al}_{2} \mathrm{O}_{3}$ & 10,43 & 14,55 & 15,78 & 18,40 & 22,40 \\
\hline $\mathrm{CaO}$ & 0,57 & 8,33 & 8,78 & 10,90 & 0,42 \\
\hline $\mathrm{Fe}_{2} \mathrm{O}_{3}$ & 4,06 & 8,33 & 8,54 & 4,10 & 7,90 \\
\hline $\mathrm{K}_{2} \mathrm{O}$ & 0,26 & 4,40 & 4,76 & 3,00 & 3,70 \\
\hline $\mathrm{MgO}$ & 1,88 & 3,01 & 3,86 & 7,30 & 4,70 \\
\hline $\mathrm{TiO}_{2}$ & 0,53 & 0,96 & 1,04 & 0,70 & 0,70 \\
\hline Kopā & 91,29 & 80,94 & 85,15 & 99,00 & 98,72 \\
\hline
\end{tabular}


Antifungālās aktivitātes noteikšanaEksperimenti noritēja Petri traukos ar iesala ekstrakta agaru (Malt extract agar, Becton \& Dickinson, ASV). Katrā Petri traukā ar $9 \mathrm{~cm}$ diametru iesvēra pa 0,05 vai 0,5 g sterila analizējamā māla vai sasmalcinātu keramikas granulu un samaisīja ar $25 \mathrm{ml}$ saškidrināta iesala ekstrakta agara, iegūstot attiecīgi $0,2 \%$ vai $2 \%$ koncentrāciju. Kad agarizētās barotnes sacietēja, uz tām uznesa pa $3 \mathrm{ml}$ sēnes Cladosporium herbarum suspensijas ar blīvumu $\mathrm{OD}_{540} 0,16$. Suspensiju vienmērīgi izkliedēja pa visu virsmu, un lieko suspensiju atsūca. Pēc tam traukus inkubēja istabas temperatūrā 5 dienas un analizēja māla materiālu ietekmi uz sēnes augšanuFizikālās un ķīmiskās analīzes

pH tika mērīts, izmantojot pH-metru AD-1405 (Adrona, Latvija). Šksidrumu elektrovadītspēja tika mērīta ar PWT HI98308 (Hanna Instruments, Maurīcija). Kontrolei un paraugu atšķaidīšanai izmantotā ūdens elektrovadītspēja bija $0,4 \mathrm{mS} / \mathrm{m}$.

\section{REZULTĀTI UN TO NOVĒRTĒJUMS}

\section{Dabisko mālu izpēte}

Pētījumā izmantoto Latvijas dabisko, neapstrādāto mālu suspensiju pH bija robežās no 7,45 līdz 7,79 (2. attēls). Planču māli nedaudz samazināja baktēriju dzīvotspēju (3. attēls), tomēr tas nebija statistiski ticami $(\mathrm{p}>0.05)$.

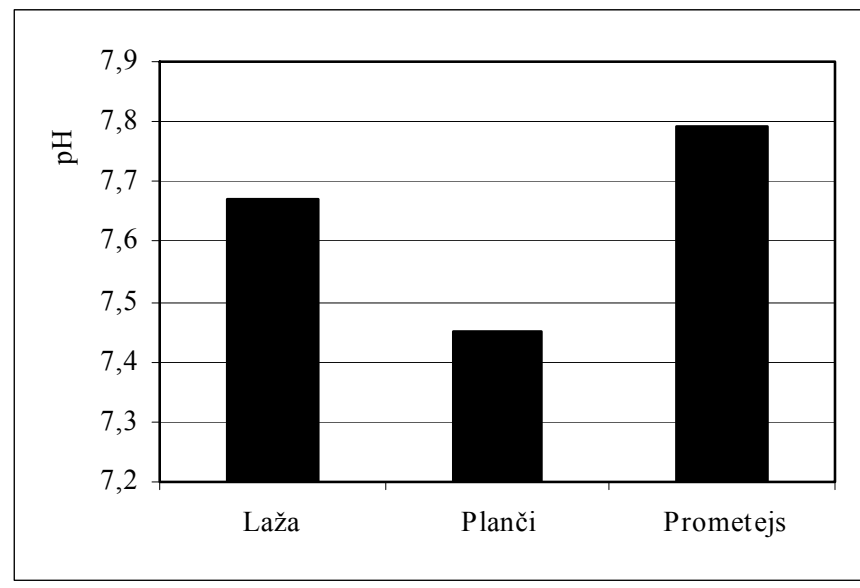

2. att. Dabisku, neapstrādātu mālu suspensijas pH pēc 4 h inkubācijas $30{ }^{\circ} \mathrm{C}$.

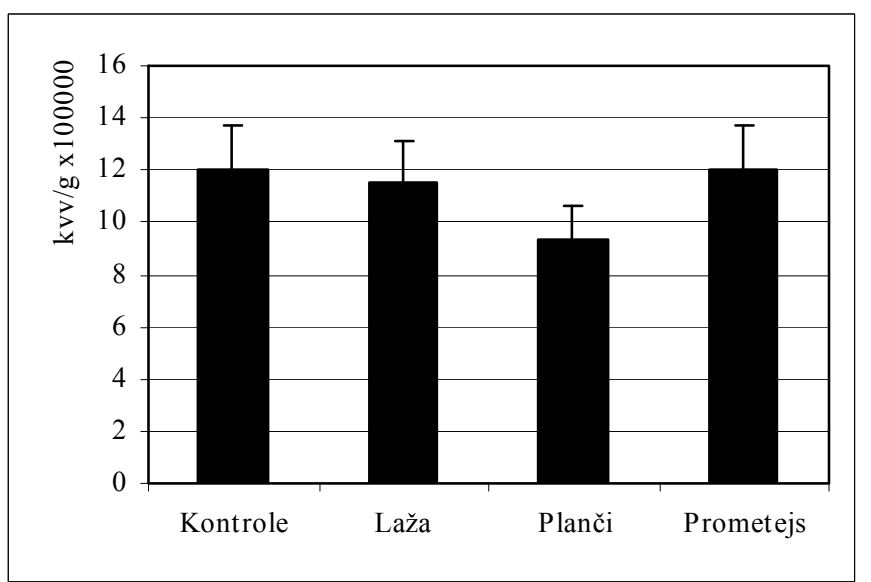

3. att. Dabisku, neapstrādātu mālu ietekme uz baktēriju $P$. putida dzīvotspēju pēc 4 h inkubācijas $30^{\circ} \mathrm{C}$.

\section{Keramikas granulu antibakteriālā iedarbība}

Mūsu pētījumos uz māliem tika adsorbētas dabā plaši izplatītas un bioremediācijā potenciāli izmantojamas sugas baktērijas - Pseudomonas putida [15]. Uz apdedzinātām keramikas granulām adsorbējās $10^{3}-10^{6}$ baktēriju kvv/g, tomēr dažādām granulām bija atšķirīga ietekme gan uz adsorbēto baktēriju daudzumu, gan arī uz baktēriju dzīvotspēju. Kvartāra perioda māla granulas samazināja dzīvo baktēriju daudzumu gan uz granulām (4. attēls), gan suspensijā. Baktericīdā iedarbība izpaudās ievērojami mazāk $20^{\circ} \mathrm{C}$ (5. attēls A) nekā $30{ }^{\circ} \mathrm{C}$ (5. attēls B). Arī pētītās devona perioda māla granulas samazināja baktēriju dz̄̄votspēju, sevišḳi inkubējot $30{ }^{\circ} \mathrm{C}$, tomēr šī ietekme bija daudz mazāka nekā kvartāra māla granulām.

Mūsuprāt, suspensijas $\mathrm{pH}$ paaugstināšanās virs 8, t.i., virs fiziologiski pieņemamām vērtībām, bija ja ne vienīgais, tad vismaz viens no iemesliem granulu baktericīdajai iedarbībai. Līdz ar to secinājām, ka kvartāra perioda Prometeja mālu šūnainā keramika nav piemērota dz̄̄vu šūnu imobilizēšanai. Var pētīt šo neorganisko materiālu antimikrobiālo īpašību izmantošanas iespējas.

Haydel ar kolēgiem [12] parādīja termostabilu, plaša spektra antibakteriālu aktivitāti ar dzelzi bagātam smektīta un illīta minerālam, kas bagātināts ar magniju un kāliju, bet tādam pašam minerālam, kas bagātināts ar kalciju, antibakteriālā iedarbība netika konstatēta.

Mpuchane ar kolēǵiem [16] pētījumi parādīja, ka mālu antimikrobiālās aktivitātes pamatā ir zems pH (zem 4). Viṇi piel̦āva, ka arī vairākiem joniem varētu būt mikrobicīds efekts.

Citā metāla oksīdu pētījumā [10] tika konstatēts, ka pret Escherichia coli visefektīvāk darbojas $\mathrm{CaO}$ un tam seko $\mathrm{MgO}$ un $\mathrm{ZnO}$, turpretim $\mathrm{ZnO}$ bija visaktîvākais pret Staphylococcus aureus. Sawai ar kolēgiem noskaidroja, ka keramikas pulvera suspensijā veidojas skābekla aktīvās formas $-\mathrm{O}_{2}$ no $\mathrm{CaO}$ un $\mathrm{MgO}$, un $\mathrm{H}_{2} \mathrm{O}_{2}$ no $\mathrm{ZnO}$ [17]. Viṇi parādīja arī to, ka no šādām suspensijām iegūti supernatanti neietekmē baktēriju augšanu. Tas apstiprinājās arī mūsu eksperimentos ar Prometeja keramikas granulu suspensiju. Suspensija viena pati, bez granulām, neietekmēja ne $P$. putida augšanu, ne dzīvotspēju (dati nav parādīti).

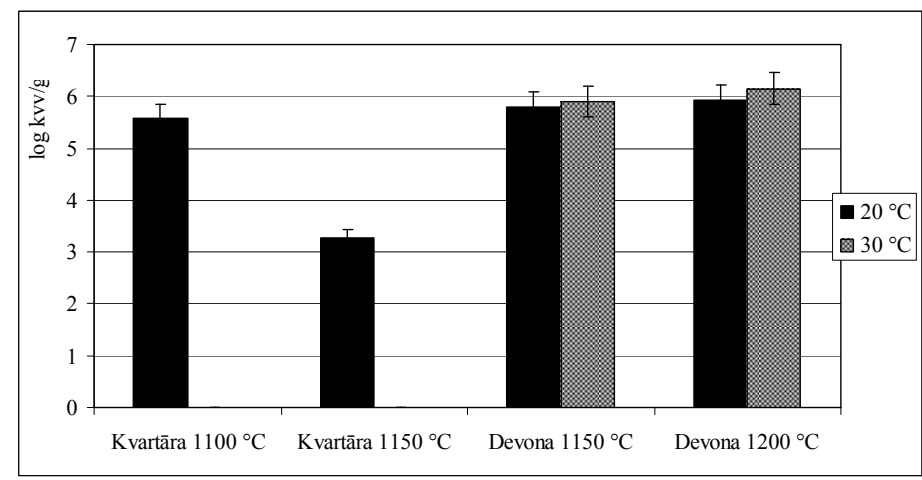

4. att. Uz apdedzinātām māla granulām adsorbēto $P$. putida daudzums pēc $4 \mathrm{~h}$ ilgas inkubācijas $20^{\circ} \mathrm{C}$ un $30^{\circ} \mathrm{C}$. 


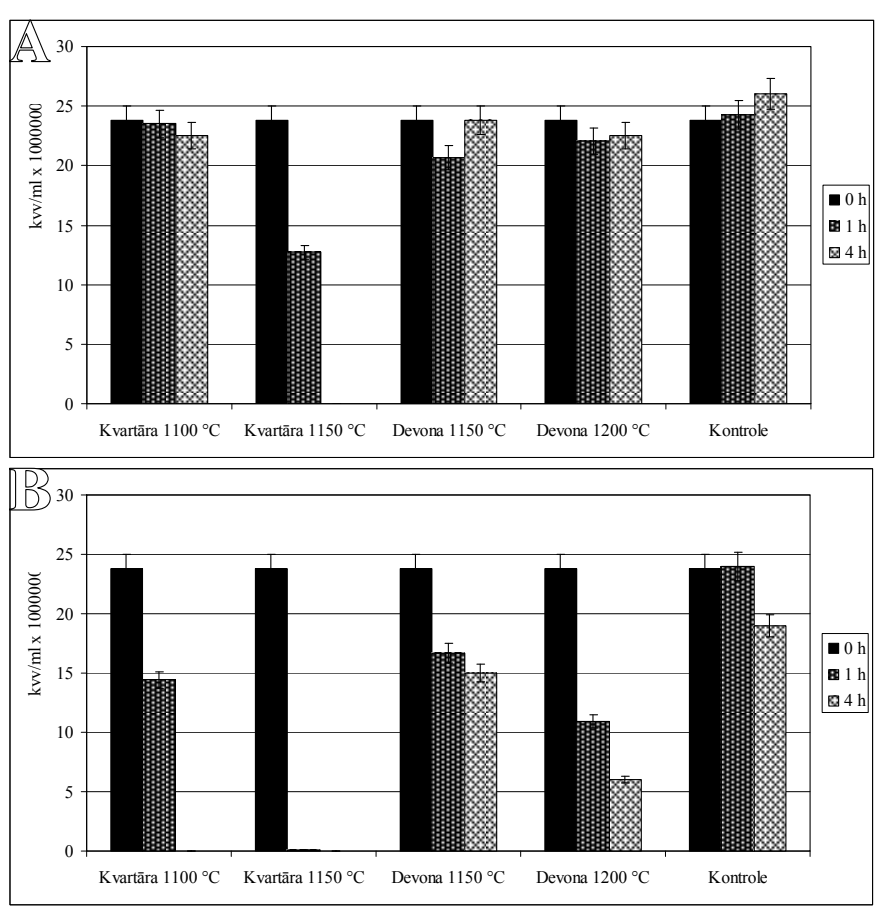

5. att. Baktēriju P. putida daudzuma izmaiņas suspensijā $(\mathrm{kvv} / \mathrm{ml})$ ar apdedzinātām māla granulām četru stundu inkubācijas laikā $20{ }^{\circ} \mathrm{C}$ (A) un $30^{\circ} \mathrm{C}$ (B) salīdzinājumā ar kontroli bez granulām.

\section{Sasmalcinātu keramikas materiālu antimikrobiālā iedarbība}

Mūsu darbā pētīta dažādā temperatūrā apdedzinātu Prometeja mālu granulu, kas sasmalcinātas līdz dažāda izmēra dalıināam, antimikrobiālā aktivitāte. Visu izmēru frakciju paraugiem tika konstatēts stiprs baktericīds efekts, kā arī pH palielināšanās suspensijā, četru stundu laikā sasniedzot 10,4510,93 materiāliem, kas apdedzināti $1000{ }^{\circ} \mathrm{C}$ temperatūrā, un 11,03-11,04 tādiem pašiem materiāliem, kas apdedzināti $800^{\circ} \mathrm{C}$ (3. tabula). Noskaidrojām, ka mālu suspensijas inhibē ne tikai baktērijas Pseudomonas putida, bet arī Staphylococus aureus un Escherichia coli. E. coli zaudēja dzīvotspēju jau pēc vienu stundu ilgas inkubācijas visu četru sasmalcināto keramikas frakciju suspensijā, bet $S$. aureus bija nedaudz izturīgākas, un to kolonijas veidojošo vienību skaits vienā stundā samazinājās par 0,2-0,3 log kvv/ml, bet četrās stundās par 0,7-1,5 $\log \mathrm{kvv} / \mathrm{ml}$ atkarībā no konkrētā materiāla (6. attēls). Pētītajiem materiāliem netika konstatēta antifungālā iedarbība.

$800{ }^{\circ} \mathrm{C}$ apdedzinātajiem materiāliem bija stiprāka antibakteriālā iedarbība nekā $1000{ }^{\circ} \mathrm{C}$ apdedzinātajiem. Kā zināms, apdedzinot lıti augstās temperatūrās, mainās kristāliskā fāze, tādēl šādi materiāli lēnāk hidratējas. Ar to varētu izskaidrot termiskās apstrādes ietekmi uz mūsu pētītajām materiālu īpašībām.

Palielinājās arī suspensiju elektrovadītspēja, un aprēķinātais Pīrsona korelācijas koeficients $r=0,84$ liecināja, ka elektrovadìtspējai ir cieša saistība ar $\mathrm{pH}$. Mūsu iepriekšējos eksperimentos tika konstatēta korelācija starp $\mathrm{pH}$ un elektrovadītspēju ūdens vidē ar dažādi sagatavotām Liepas māla granulām un Prometeja māla granulām [18]. Iespējams, ka pH izmaiñas un ar tām saistīto māla baktericīdo efektu izraisa no māliem izdalītie joni, galvenokārt hidroksīda joni, kas rodas, bāziskajiem māla oksīdiem, tādiem kā $\mathrm{CaO}$ un $\mathrm{MgO}$, reaǵējot ar ūdeni. Latvijas kvartāra perioda māli ir bagāti ar tiem [19]. Mūsu pētījumā izmantotie māli saturēja 8,78 \% $\mathrm{CaO}$ un 3,86\% $\mathrm{MgO}$ (2. tabula).

\section{Ķ̄̄miski modificètu mālu antimikrobiālà iedarbība}

Mālu organokompleksu sastāvā esošās organiskās vielas oktadeciltrimetilamonija hlorīds (ODTMA $\mathrm{Cl}$ ) un heksadeciltrimetilamonija bromīds (HDTMA Br) pieder pie antimikrobiāliem četraizvietotiem amonija sāliem, kas pazīstami kā katjonu virsmas aktīvās vielas (jeb VAV) [20]. Abi VAV saturošie māli samazināja suspensijas pH līdz 2,502,36, palielināja tās elektrovadītspēju un iznīcināja baktērijas (3. tabula). Mālu bagātināšanas procesā iegūtie māli arī nedaudz samazināja $\mathrm{pH}, \bar{l} \mathrm{~d} \mathrm{z} 4,56$, un tiem bija arī neliela baktericīda iedarbība.

Mālu organokomplekss ar abām virsmas aktīvajām vielām oktadeciltrimetilamonija hlorīdu un heksadeciltri-metilamonija bromīdu - uzrādīja arī fungicīdu efektu. Vielu ietekme bija atkarīga no to koncentrācijas. 0,2 \% koncentrācijā sēnes Cladosporium herbarum augšana bija kavēta, bet $2 \%$ koncentrācijā sēne neauga nemaz. Dabiskie un bagātinātie Saltišksu atradnes māli neietekmēja sēnes augšanu.

3. TABULA

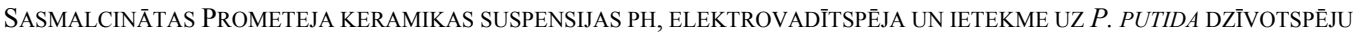

\begin{tabular}{|c|c|c|c|c|c|}
\hline \multirow{2}{*}{ Māla materiāli } & \multicolumn{2}{|c|}{$\mathrm{pH}$} & \multirow{2}{*}{$\begin{array}{c}\text { Elektrovadītspēja pēc } \\
4 \mathrm{~h}, \mathrm{mS} / \mathrm{cm}\end{array}$} & \multicolumn{2}{|c|}{ Baktēriju dz̄ivotspēja, \% } \\
\hline & $1 \mathrm{~h}$ & $4 \mathrm{~h}$ & & $1 \mathrm{~h}$ & $4 \mathrm{~h}$ \\
\hline \multicolumn{6}{|l|}{ Sasmalcinātas Prometeja māla granulas } \\
\hline Apdedzinātas $1000^{\circ} \mathrm{C}$, frakcija $<200 \mu \mathrm{m}$ & 10,34 & 10,45 & 0,12 & 3,0 & 0,0 \\
\hline Apdedzinātas $1000^{\circ} \mathrm{C}$, frakcija $>200 \mu \mathrm{m}$ & 10,73 & 10,93 & 0,30 & 0,0 & 0,0 \\
\hline Apdedzinātas $800^{\circ} \mathrm{C}$, frakcija $>200 \mu \mathrm{m}$ & 11,02 & 11,04 & 0,76 & 0,7 & 0,0 \\
\hline Apdedzinātas $800^{\circ} \mathrm{C}$, frakcija $<200 \mu \mathrm{m}$ & 11,08 & 11,03 & 0,84 & 0,0 & 0,0 \\
\hline \multicolumn{6}{|l|}{ Saltišķu māli } \\
\hline Dabiski māli & 8,93 & 8,63 & 0,16 & 100,0 & 90,0 \\
\hline Bagātināti māli & 4,86 & 4,56 & 0,86 & 85,8 & 66,0 \\
\hline Mālu organokomplekss ar ODTMA Cl & 2,36 & 2,48 & 8,38 & 0,0 & 0,0 \\
\hline Mālu organokomplekss ar HDTMA Br & 2,50 & 2,40 & 7,78 & 0,0 & 0,0 \\
\hline
\end{tabular}




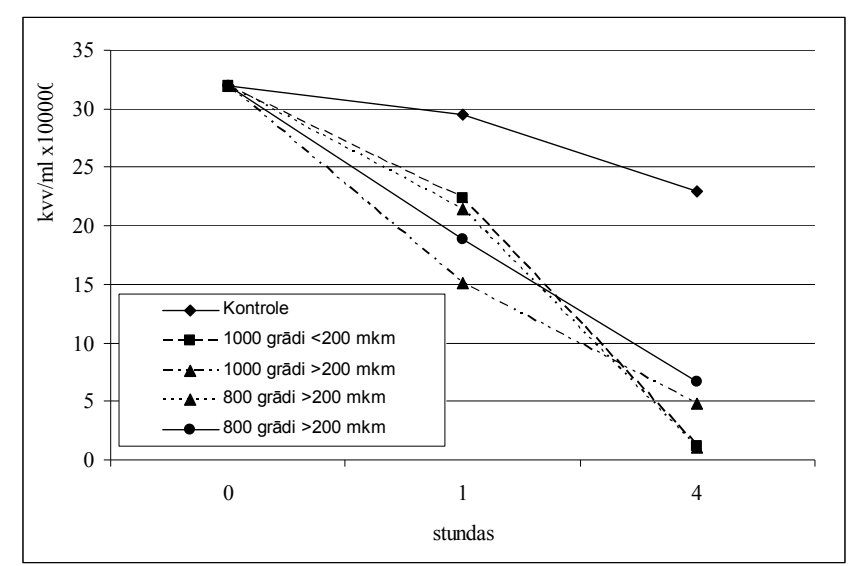

6. att. Dzīvotspējīgo Staphylococcus aureus daudzuma izmaiṇas sasmalcināto Prometeja māla granulu suspensijā.

\section{SECINĀJUMI}

Iegūtie rezultāti liecina, ka pētītajiem Latvijas dabiskajiem māliem nepiemīt antimikrobiāla aktivitāte. Kvartāra perioda Prometeja atradnes māla keramikas granulas, gan veselas, gan sasmalcinātas, ūdens vidē nelielā koncentrācijā inhibēja baktēriju augšanu, bet lielākā koncentrācijā nonāvēja baktērijas, t.i., iedarbojās bakteriostatiski un baktericīdi. Keramikas materiālu antimikrobiālo aktivitāti iespējams izskaidrot ar $\mathrm{pH}$ palielināšanos suspensijā, kas notiek hidratējoties $\mathrm{CaO}$ un citiem bāzisko metālu oksīdiem. Katjonu virsmas aktīvās vielas ODTMA $\mathrm{Cl}$ un HDTMA Br saturoši māli uzrādīja gan antibakteriālu, gan antifungālu aktivitāti. Paveras iespējas izstrādāt jaunas antimikrobiālu māla materiālu iegūšanas tehnologijas un produktus.

\section{PATEICĪBAS}

Pateicamies Dr. habil. sc. ing. V. Švinkam un Dr. sc. ing. R. Švinkai par māla un keramikas granulu ar mērķa īpašībām sagatavošanu. Pētījums veikts Valsts pētījumu programmas „Vietējo resursu (zemes dz̄̄lu, meža, pārtikas un transporta) ilgtspējīga izmantošana - jauni produkti un tehnologijas (NatRes)” projekta Nr. 1 ,Jaunu tehnologiiju izstrādāšana inovatīvu produktu radīšanai no Latvijas zemes dzīḷu resursiem (Zemes dzīles)" ietvaros.

\section{LITERATŪRAS SARAKSTS}

[1] Kuršs, V., Stinkule, A. Derīgie izrakteņi. Latvijas Universitāte, Rīga, 1999, 112 lpp.

[2] Kariminiaae-Hamedaani, H.R., Kanda, K., Kato, F. Wastewater treatment with bacteria immobilized onto a ceramic carrier in an aerated system. J. Biosci. Bioeng., 2003, vol. 95, p. 128-132.

[3] Grundmann, S., Fu $\beta$, R., Schmid, M., Laschinger, M., Ruth, B., Schulin, R., Munch, J.C., Schroll, E. Application of microbial hot spots enhances pesticide degradation in soils. Chemosphere, 2007, vol. 68, p. 511-517. http://dx.doi.org/10.1016/j.chemosphere.2006.12.065

[4] Berzins, A., Potapova, K., Strikauska, S., Muter, O. Combination of straw and ceramic materials for biofiltration of volatile hydrocarbons. Scientific Journal of RTU Material Science and Applied Chemistry, 2012, vol. 26, p. 127-133.

[5] Muter, O., Potapova, K., Nikolajeva, V., Petrina, Z., Griba, T., Patmalnieks, A., Svinka, R., Svinka, V. Comparative study on bacteria colonization onto ceramic beads originated from two Devonian clay deposits in Latvia. Scientific Journal of RTU Material Science and Applied Chemistry, 2012, vol. 26, p. 134-140.
[6] Courvoisier, E., Dukan, S. Improvement of Escherichia coli growth by kaolinite. Appl. Clay Sci., 2009, vol. 44, p. 67-70. http://dx.doi.org/10.1016/j.clay.2009.01.010

[7] Lynda, B.W., Shelley, E.H., Rossman, F.G., Dennis, D.E. Chemical and mineralogical characteristics of French green clays used for healing. Clays and Clay Minerals, 2008, vol. 56, p. 437-542. http://dx.doi.org/10.1346/CCMN.2008.0560405

[8] Williams, L.B., Haydel, S.E. Evaluation of the medicinal use of clay minerals as antibacterial agents. International Geology Review, 2010, vol. 52, p. 745-770. http://dx.doi.org/10.1080/00206811003679737

[9] Gant, V.A., Wren, M.W.D., Rollins, M.S.M., Jeanes, A., Hickok, S.S. Three novel highly charged copper-based biocides: safety and efficacy against healthcare-associated organisms. J. Antimicrob. Chemother., 2007, vol. 60, p. 294-299. http://dx.doi.org/10.1093/jac/dkm201

[10] Sawai, J. Quantitative evaluation of antibacterial activities of metallic oxide powders $(\mathrm{ZnO}, \mathrm{MgO}$ and $\mathrm{CaO})$ by conductimetric assay. $J$. Microbiol. Methods, 2003, vol. 54, p. 177-182. http://dx.doi.org/10.1016/S0167-7012(03)00037-X

[11] Hewitt, C.J., Bellara, S.R., Andreani, A., Nebe-von-Caron, G., McFarlane, C.M. An evaluation of the anti-bacterial action of ceramic powder slurries using multi-parameter flow cytometry. Biotechnol. Lett., 2001, vol. 23, p. 667-675. http://dx.doi.org/10.1023/A:1010379714673

[12] Haydel, S.E., Remenih, C.M., Williams, L.B. Broad-spectrum in vitro antibacterial activities of clay minerals against antibiotic-susceptible and antibiotic-resistant bacterial pathogens. J. Antimicrob. Chemother., 2008, vol. 61, p 353-361. http://dx.doi.org/10.1093/jac/dkm468

[13] Williams, L.B., Holland, M., Eberl, D.D. Natural antibacterial clay minerals. Mineral Soc. Bull., 2004, vol. 139, p. 3-8.

[14] Kostjukovs, J., Actiņš, A., Sarceviča, I., Karasa, J. A method for extraction of smectites from low smectite content clays. EU patent No. EP $2465820 \mathrm{~A} 1,2010$.

[15] Timmis, K.N. Pseudomonas putida: a cosmopolitan opportunist par excellence. Environ. Microbiol., 2002, vol. 4, p. 779-781. http://dx.doi.org/10.1046/j.1462-2920.2002.00365.x

[16] Mpuchane, S.F., Ekosse, G.I., Gashe, B.A., Morobe, I., Coetzee, S.H. Microbiological characterisation of southern African medicinal and cosmetic clays. Int. J. Environ. Health Res., 2010, vol. 20, p. 27-41. http://dx.doi.org/10.1080/09603120903254025

[17] Sawai, J., Kawada, E., Kanou, F., Igarashi, H., Hashimoto, A., Kokugan, T., Shimizu, M. Detection of active oxygen generated from ceramic powders having antibacterial activity. J. Chem. Eng. Jpn., 1996, vol. 29, p. 627-633. http://dx.doi.org/10.1252/jcej.29.627

[18] Nikolajeva, V., Griba, T., Petriņa, Z. Dažādu Latvijas mālu šūnainās keramikas granulu pielietošanas iespējas biotehnologijā. Scientific Journal of RTU Material Science and Applied Chemistry, 2011, vol. 24, p. 106-109.

[19] Sedmalis, U. Šperberga, I. Porainu keramzīta tipa materiālu ieguve no kārtainiem silikātiem tos termiski apstrādājot $600-1250{ }^{\circ} \mathrm{C}$ temperatūras intervāala. Scientific Journal of RTU Material Science and Applied Chemistry, 2009, vol. 19, p. 88-92.

[20] Viera, D.B., Carmona-Ribeiro, A.M. Cationic lipids and surfactants as antifungal agents: mode of action. J. Antimicrob. Chemother., 2006, vol. 58, p. 760-767. http://dx.doi.org/10.1093/jac/dk1312

Vizma Nikolajeva, Dr. biol., docent, senior researcher

Department of Microbiology and Biotechnology, Faculty of Biology, University of Latvia

Address: 4 Kronvalda blvd., Riga LV-1010, Latvia

E-mail: vizma.nikolajeva@lu.lv

Member of the Microbiological Society of Latvia

Tatjana Griba, MSc. biol., laboratory assistant

Institute of Microbiology and Biotechnology, University of Latvia

Address: 4 Kronvalda blvd., Riga LV-1010, Latvia

E-mail: mrs.griba@gmail.com

Member of the Microbiological Society of Latvia

Zaiga Petriṇa, MSc. biol., research assistant

Department of Microbiology and Biotechnology,

Faculty of Biology, University of Latvia

Address: 4 Kronvalda blvd., Riga LV-1010, Latvia

E-mail: zaiga.petrina@lu.lv

Member of the Microbiological Society of Latvia 
Jūlija Karasa, MSc. chem., chemist Department of Physical Chemistry, Faculty of Chemistry, University of Latvia
Address: 48 Kr. Valdemara str., Riga LV-1013, Latvia

E-mail: julija.karasa@lu.lv

Vizma Nikolajeva, Tatjana Griba, Zaiga Petrina, Julija Karasa. Antimicrobial Activity of Natural and Treated Clays

Usually, clay creates a suitable living environment for microorganisms, and some clays and clay materials possess antimicrobial properties that can be used, for example, in medicine and in the production of construction materials. Antimicrobial activity of natural clay and treated clay materials was studied. The results showed that the studied Latvian natural clay samples were devoid of antimicrobial activity. Porous clay ceramic granules made from quaternary deposits of Prometejs clay and sintered at the temperatures from $800{ }^{\circ} \mathrm{C}$ to $1150{ }^{\circ} \mathrm{C}$, whole or crushed, in low concentration inhibited the growth of bacteria (Gram-negative Pseudomonas putida and Escherichia coli, and Gram-positive Staphylococcus aureus) in the aquatic environment. At higher concentration, the bactericidal effect was noticed. Suspension alone, without whole or crushed granules, had no effect on the growth or viability of bacteria. Studied ceramic materials showed no antifungal activity. Pearson correlation coefficient $r=0.84$ showed a close relationship between $\mathrm{pH}$ value and electrical conductivity of the suspension. Attempts were made to explain the observed antibacterial effect with the formation of hydroxyl ions and increase of $\mathrm{pH}$ in the suspension that occurred during hydration of $\mathrm{CaO}$ and other oxides of alkali and alkaline earth metals. Chemically treated clay containing cationic surfactants octadecyltrimethylammonium chloride (ODTMA) and hexadecyltrimethylammonium bromide (HDTMA) showed both antibacterial and antifungal activity. Clay samples enriched with surfactants reduced the suspension $\mathrm{pH}$ to $2.50-2.36$, increased its electrical conductivity and destroyed microorganisms. The opportunity for the development of new antimicrobial clay material technologies and products was suggested.

\section{Визма Николаева, Татьяна Гриб, Зайга Петриня, Юлия Карась. Антимикробная активность натуральной и обработанной глины}

Обычно глина является дружественной средой для микроорганизмов, но иногда глина проявляет антимикробиальные свойства, которые можно использовать в медицине и производстве стройматериалов. В работе были изучены натуральные и обработанные глины. Результаты показали, что природная латвийская глина не обладает антимикробиальным эффектом. Пористые керамические гранулы, изготовленные из глины месторождения Прометей, четвертичный период, и обожжённые при температуре от $800{ }^{\circ} \mathrm{C}$ до $1150^{\circ} \mathrm{C}$, цельные или измельчённые в небольших концентрациях замедляли рост бактерий (Грам (-) Pseudomonas putida и Escherichia coli, и Грам (+) Staphylococcus aureus) в водной среде. Большие концентрации производили бактерицидный эффект. Эффект не наблюдался при отсутствии цельных или измельчённых гранул в суспензии. Изучаемые гранулы не оказали противогрибкового действия. Коэффициент корреляции Пирсона $r=0.84$ продемонстрировал тесную связь между рН и электропроводностью суспензии. Антибактериальный эффект можно пытаться объяснять образованием гидроксильных ионов и, как следствие, повышением уровня pH. Химически обработанная глина содержала катионные поверхностно-активные вещества (ПАВ): октадецил триметил хлорид аммония и гексадецил триметил бромид аммония, которые проявили антибактериальную и противогрибковую активность. Образцы глины, обогащённые ПАВ, снизили уровень $\mathrm{pH}$ суспензии до 2.50-2.36, что увеличило электропроводность и уничтожило микроорганизмы. В работе предложены возможности развития новых технологий и продуктов антимикробных глинистых материалов. 